ORIGINAL ARTICLE

\title{
Pickled essence of Englishman: Thomas Lovell Beddoes-time to unearth a neglected poet?
}

\author{
I Bamforth
}

J Med Ethics; Medical Humanities 2004;30:36-40. doi: 10.1136/jmh.2004.000150

\begin{abstract}
Thomas Lovell Beddoes (1803-1849) was a doctor and intermittently brilliant poet whose explorations of "the florid Gothic in poetry" (his words) offer some of the most haunting, claustrophobic, and grotesque verse in the English language. Son of the pioneering Bristol scientist Thomas Beddoes and nephew of Maria Edgeworth the novelist, he stemmed, like Mary Shelley, author of the celebrated novel Frankenstein, from a line of influential freethinkers. This article situates Beddoes's work in the transition from the confident empiricism of the eighteenth century to the nineteenth century's imaginative reaction to social and intellectual life after the Napoleonic wars. Having spent most of his adult life in Germany (where he studied anatomy with the famous biologist Blumenbach) and latterly Switzerland, Beddoes engaged in radical politics, dabbled in the occult, and may even have encountered the German doctor/playwright Georg Büchner, whose career parallels his own. Beddoes hoped that by reading the body literally, in terms of its material structure, he would be able to bring about a revival of English theatre. Inevitable defeat led him to develop his signature form of abject irony. In view of the current interest in semiotics (a development of medical semiology), and the subterranean analogies in Beddoes's writing between the corpus and the corpse, his reputation ought to be rescued from the "critical pickle".
\end{abstract}

Correspondence to: Kempf, 67000 Strasbourg France; lainBAMFORTH@ wanadoo.fr

Revised version received 1 December 2003 Accepted for publication 21 February 2004
.......................
Keats, who has a more obvious claim to be remembered as the pre-eminent doctor/poet of the Romantic era.

Born in Shropshire, in 1803, Beddoes came from a distinguished freethinking background on both sides of his family. His aunt was the novelist Maria Edgeworth, his grandfather the radical educationalist Richard Lovell Edgeworth. His father, Dr Thomas Beddoes, chemist, physician, educator, pamphleteer, and inventor, ${ }^{3 *}$ was a close friend of Coleridge (who consulted him for medical problems, real and imagined) and an elder colleague of Humphry Davy. Together with James Watt and Josiah Wedgwood they founded, in 1799, the famous Pneumatic Institute at Clifton in the West Country where, by cautious auto-experimentation, they ascertained the effects of entire families of gases on the living body. One outcome of their "gaseous enthusiasm" was the discovery that, when inhaled in an admixture of oxygen, nitrous oxide (somewhat better known later for its inebriating effects as "laughing gas") "seemed capable of destroying pain" and could "probably be used with advantage during surgical operations". Women in labour still benefit from their discovery today. This early analgesic is a splendid enactment of the elder Beddoes's belief in experimentation as a means to practical improvement. He was a straight talking man: his vocal support for the French Revolution had cost him his position as reader in chemistry at Oxford. In the atmosphere of suspicion and apprehension that cloaked Britain in the period after the revolution, speculative scientists were not highly regarded. They were seen, in fact, as a threat to society; and as Roy Porter has written, Thomas Beddoes learned that the dividing line between "experimentalism" and quackery was a fine one indeed: "I must expect to be decried by some as a silly projector, and by others as a rapacious empiric," he wrote to his friend, the poet/botanist Erasmus Darwin. ${ }^{4}$ From the relative safety of Bristol, he blasted vested interests and landed Tories who connived to keep the people ignorant, and

*A fuller account of Thomas Beddoes's life and times as a pioneering scientist is to be found in Roy Porter's Flesh in the Age of Reason. ${ }^{3}$ 


\section{DREAM-PEDLARY}

If there were dreams to sell, What would you buy?

Some cost a passing bell; Some a light sigh,

That shakes from life's fresh crown

Only a roseleaf down.

If there were dreams to sell, Merry and sad to tell,

And the crier rung the bell, What would you buy?

A cottage lone and still, With bowers nigh,

Shadowy, my woes to still, Until I die.

Such pearl from life's fresh crown

Fain would I shake me down.

Were dreams to have at will,

This would best heal my ill, This I would buy.

But there were dreams to sell, Ill didst though buy;

Life is a dream, they tell, Waking, to die.

Dreaming a dream to prize,

Is wishing ghosts to rise;

And, if I had the spell

O call the buried, well,

Which one would I?

If there are ghosts to raise,

What shall I call,

Out of hell's murky haze,

Heaven's blue hall?

Raise my loved long lost boy

To lead me to his joy.

There are no ghosts to raise;

Out of death lead no ways;

Vain is the call.

Know'st thou not ghosts to sue?

No love thou hast.

Else lie, as I will do,

And breathe thy last.

So out of life's fresh crown

Fall like a rose-leaf down.

Thus are the ghosts to woo;

Thus are all dreams made true,

Ever to last!' denounced Pitt's war taxes as vigorously as he championed "healthy living". Here was a man so unconventional in his habits he dissected animals in front of his children: this was part of his programme of "teaching children accurately to distinguish the parts of the body". Thomas Lovell Beddoes was five when his father died, but there is little doubt, in Frances Wilson's choice words, that "the curious experiences of his childhood worm their way into Beddoes's obsessive poetry".

Having burst into poetry as a young man at Charterhouse and Oxford, Beddoes just as suddenly left it, abandoning it at a moment when he seemed poised to fill the place vacated by John Keats and Percy Bysshe Shelley (the latter had been expelled from the same college, Pembroke, eight years earlier). This inability to see a thing through was to become a lifelong trait. His first (and only completed) verse tragedy, the five act drama The Brides' Tragedy, was published to acclaim in 1822, when the poet was 19. In the next two years he worked on three new tragedies, The Last Man, Love's Arrow Poisoned, and The Second Brother, and made the acquaintance of the most famous of the "English Jacobins", William Godwin, author of Enquiry Concerning Political Justice (1793), a plea for a new system of "universal benevolence" in which virtue would emerge unprompted-as in Rousseau's philosophy-from the exercise of reason and free will. He also met Godwin's recently widowed daughter Mary Shelley, whose second Gothic novel of anticipation, also called The Last Man (1826), examines a threat even more menacing to society than that of male egotism: the plague. Interrupting his arts degree, Beddoes left Oxford in 1825-the year after his mother's death in Florence-to study the flesh in Göttingen, an old Hanoverian university with a strong medical faculty. He distinguished himself there for his academic brilliance as well as his unruliness. Under the effect of German idealism and his readings of various occult and Talmudic writers, his poems were becoming more outrageously Jacobean. His presumed lover and fellow medical student, Benjamin Bernhard Reich, a Russian Jew, encouraged him to develop his eschatological studies on the "bone of Luz", a structure which the Talmudists believed to be the irrefragable seat of the soul, every substance having an essence, or what alchemists called flos (flower). Leibniz was perhaps the last philosopher, in his notes appended to a book on the resurrection by Robert Boyle, to make a serious attempt to identify the notion of essence with a metaphysics of rebirth: "I hold that the flower of substance is our body; that this flos substantiae persists perpetually in all changes; that this was foreshadowed by the Luz of the Rabbis...It is diffused through the whole body; somehow it comprises the whole form." ${ }^{6}$

It was at this time, too, studying in Göttingen with the famous comparative anatomist Johann Friedrich Blumenbach (1752-1840), who has also gone down in history as one of the first ethnographers, that he started work on his masterpiece Death's Jest-Book, a surreal mortality play. ${ }^{7}$ Masterpiece, that is, in the sense that any monster made of spare parts is all of a piece. Death's Jest-Book owes its existence to some stealthy grave robbing, Dean Swift's keen sense of disgust, a corset loaned from Melpomene, and lumps of wax from Tieck's cabinet of ironies. One more production, it would seem, from "the workshop of filthy creation,"** though Beddoes's early account of it, in a letter to his friend Kelsall, proposes a new dramatic style, able to soar above its origins in the anatomy table and language primer:

Again, even as a dramatist, I cannot help thinking that the study of anaty , physiol-, psych-, \& anthropology applied to and illustrated by history, biography and works of imagination is that $w^{\text {h }}$ is most likely to assist one in producing corrected and masterly delineations of the passions...The studies then of the dramatist \& physician are closely, almost inseparably, allied; the application alone is different; but is it impossible for the same man to combine these two professions, in some degree at least?

Death's Jest-Book dares an unnerving, hollow laugh at the Grim Reaper which may well have been spurred by his signal failure, as he wrote to his friend Thomas Forbes Kelsall, to find any kind of "shadow of a proof or probability of an afterexistence, both in the material and immaterial nature of

** This potent phrase comes from Mary Shelley's Frankenstein. 
man". The bone of Luz, Beddoes admits in the notes to Death's Jest-Book, is "beyond a doubt the os coccygis of the osteologians": the coccyx or tailbone (Beddoes, ${ }^{7}$ pp 122-3).

Beddoes's loss of faith in speculative science as an ersatz religion and his inability to find an intellectual solution for the structural irony built into his masterpiece, the unmasking of death itself, resembles that of another young anatomist/ writer, Georg Büchner (1813-1837), best known for his fragmentary play Woyzeck (1836). Beddoes's line about "The crevice 'twixt two after-dinner minutes,/ The crack between a pair of syllables" has the same abyssal dimensions as Woyzeck's despairing remark in Büchner's play of the same name:

\section{... you almost get the urge to bang a nail into the sky and hang yourself, just because of the tiny dash between Yes and No. ${ }^{9}$}

Büchner's father, also a doctor, also used to perform dissections with his son as assistant. There is a suggestion that both anatomist/writers met in their travels along the Rhine in the 1830s: it would have been a most interesting coincidence of minds since by the measure of their time-not least in reactionary Germany-they were political radicals, though nothing more radical than what today would be called democrats.

Death's Jest-Book, which was first completed in 1828, did not go down well when he showed it to friends in England, and their critical comments drove him to spend the last 20 years of his life revising it. Like all his dramatic pieces it is unstageable, as if his characters were untethered forms of one commanding idea: "All the characters seem to declaim into the void, and none answer the others" (Donner, ${ }^{8} \mathrm{p} \mathrm{xl}$ ). Set in late 13th century Germany, with frequent sorties to the Nile, it has elements of blood feud, quest, betrayal, revolution, betrayal, revolution, fratricide, and sorcery. Yet it is shot through with the most vividly lyrical passages and oddly memorable figures: Beddoes's Old Adam-the "carrion crow"- - seems to anticipate Ted Hughes's baleful anthropomorphic creature of the same name. "What is the lobster's tune when he is boiled," a central character asks, recalling Belacqua's appalled question in one of Beckett's best early stories. Beddoes's disdain and poise recall the early poems of T S Eliot: the creepy title of one arch sequence is "The oviparous tailor". It is all hotly Jacobean, except for the bodies cooling and chilling everywhere-“"cool as an ice-drop in a dead man's eye" as another play has it.

Indeed, Death's Jest-Book proved to be Beddoes's albatross. Having set out to produce a revenge play in the Kidd or Webster manner, he allows his play to be disrupted by sardonic, incongruous elements-his sense of measure carried away by a rush of cosmic mockery: "The spell of my creation is read backwards". Much of the play turns on the family resemblance between the words "sceptre" and "spectre". Even "Noah's world washing" rain curdles in the acid atmosphere of Beddoes's drama; and the vampire weary reader may sometimes have to suppress a giggle at yet another preposterous assault on the necromantic sublime. The "bold trampling hope" of English drama recognises, in his talk of grave robbing and dismemberment, that he cannot outdo Shakespeare. He cannot even "do" Shakespeare without overdoing him. His drama, like the revival theatre he had criticised in an early essay, is "a haunted ruin" (Donner, ${ }^{8}$ p 595). ${ }^{* * *}$

Belatedness is the wooden star in Beddoes's universe, and the atmosphere poisoned: no matter how brilliant, a parodist

*** Donner is quoting from a letter written by Beddoes in January 1825. is always beholden to the object of his parody. Like his zany Mandrake in Death's Jest-Book, Beddoes has learned to wear fool's motley, although awareness of his predicament merely serves to intensify his discomfort. His register is wildly mixed: piss and vinegar colloquialisms break in on passages of controlled description like a crowd of Cockney hearties at a gathering of rather genteel lycanthropes. Letters of the mid-1820s to his faithful friend Kelsall, with their mention of "windeggs" and galvanism, make him sound rather medieval-Faust in his laboratory trying to patent a new meat extract: pickled essence of Englishman. Fee-fie-fofum. What makes Beddoes's drama tonally unique is his self lacerating irony, and his wholly materialist conviction that medicine (anatomy) and poetry could be mutually sustaining in the service of a transcendent psychology. Testimony to his brilliance as a writer of verse, and a breezy statement of intent, comes in a doggerel letter he wrote in 1826 to his friend Bryan Waller Procter ("Barry Cornwall") ( see box Verse letter to B W Procter on the genesis and ambitions of Death's Jest-Book).

\section{There is, truth be told, very little space, logically speaking,} in which mirth and despair might cohabit.

Perhaps the closest parallel to Beddoes's plea for "rebellion/ Against all kings, even Death" is indeed the confession of Dr Victor Frankenstein, maker of "hideous progeny", in Mary Shelley's novel of forbidden knowledge and overweening ambition. ${ }^{10}$ Even at the slender age of 19, the age at which she wrote her horror thriller Frankenstein, Mary Shelley had an unerringly critical instinct about where to locate the blind spot of a generation of self proclaimed (male) geniuses and domestic tyrants. Married to the poet Beddoes admired above all his contemporaries, a man whose idealised programme for the reform of society was not at all dissimilar to that of Beddoes senior or William Godwin (Percy Shelley was, for some time, a fervent Godwinite who went so far as to esteem Godwin "a luminary too dazzling for the darkness which surrounds him" $\dagger$ ), Mary's scepticism about her father's rational principles is salutary. Her annotation to her husband's famous poem, Prometheus Unbound-“"Shelley believed that mankind had only to will that there should be no evil, and there would be none"-actually damns his vacant idealism. Victor Frankenstein also believed that he merely had to will the creation of a living species immune to disease and death, and it would come about. When he confesses to his error in making the monster, having (like Beddoes) confused natural philosophy with the vaunting ambitions of alchemy, he blames his father for not deflecting his youthful interest in mystical and occult writings: "If...my father had taken the pains to explain to me that the principles of Agrippa had been entirely exploded, and that a modern system of science had been introduced, which possessed much greater powers than the ancient, because the powers of the latter were chimerical, while those of the former were real and practical; under such circumstances I should certainly have thrown those of Agrippa aside and have contented my imagination, warmed as it was, by returning with greater ardour to my former studies. It is even possible that the train of my ideas would never have received the fatal impulse that led to my ruin." Victorian fathers clearly had a lot to answer for.

†Although Godwin, who preached property-sharing in addition to the dissolution of the "fraudulent" institution of marriage, was happy to accept money from Shelley, heir to an estate in Sussex, he could never come to terms with the fact that Mary, his daughter by the distinguished feminist Mary Wollstonecraft, should elope with a married man. 
Letter of December 1825 from Göttingen to

Thomas Forbes Kelsall outlining Beddoes's plans for a new kind of medicoliterary drama

Again, even as a dramatist, I cannot help thinking that the study of anat' ${ }^{y}$, physiol-, psych-, \& anthropology applied to and illustrated by history, biography and works of imagination is that $w^{h}$ is most likely to assist one in producing corrected and masterly delineations of the passions: great light $w^{d}$ be thrown on Shakespeare by the commentaries of a person so educated. The studies then of the dramatist \& physician are closely, almost inseparably, allied; the application alone is different; but is it impossible for the same man to combine these two professions, in some degree at least? The science of psychology, mental varieties, has long been used by physicians, in conjunction with the corresponding corporeal knowledge, for the investigation \& removal of immaterial causes of disease; it still remains for some one to exhibit the sum of his experience in mental pathology \& therapeutics, not in a cold technical dead description, but a living semiotical display, a series of anthropological experiments, developed for the purpose of ascertaining some important psychical principle-ie a tragedy. Thus far to show you that my studies, pursued as I pledge myself to pursues them, are not hostile, but rather favourable to the development of a germ $w^{h}$ I $w^{d}$ fain believe within me. You will say, "this may be theoretically true, but no such physician has every yet appeared." I shall have great satisfaction in contradicting you, as Dr Johnson did the man who denied motion. ${ }^{8}$

Part of the genuine pathos of Mary Shelley's novel resides in the fact that were it not for parental love we would all be a species of Frankenstein's Creature, cast into the world and demanding to know who we are, what we are, and whence we come. She touches a dimension of sympathetic experience that is absent (and not greatly missed) among Beddoes's "congregated monsters of the deep". It is worth recalling that the great intellectual issue of the post-Napoleonic period, and the ferment which gave mythic form to Frankenstein, was the vitalist dispute (1814-19), in which two professors at the Royal College of Surgeons of London joined in public debate. The more senior of the two, John Abernethy, insisted that some "subtile, mobile, invisible substance" —call it soul, call it electricity or "something analogous" -was required to animate animal matter. Byron's doctor, Polidori, recorded a similar conversation between himself and Percy Shelley on June 15, 1816; the following day Mary, who was often their silent auditor, joined them at Byron's Villa Diodati, on the shore of Lake Geneva, for the famous session of ghost stories. In order to show that there was no means of abstracting the animating essence from the animal-even in man, "the most perfect of domesticated animals" - the materialist defence of Lawrence, Percy Shelley's personal physician and a friend of the family, leaned heavily on the work of a certain German anatomist (or "biologist," as Lawrence called him, introducing the word to English): J F Blumenbach. ${ }^{11}$

Depressed, perhaps by the intractable problems with what he himself called his "unhappy, strange conglomerate", Beddoes got drunk in public and was expelled from Göttingen in 1829. He completed his MD at Würzburg in 1831, though he was deported the following year by the Bavarian government as a political agitator. By now he was writing inflammatory pamphlets in his adopted German. He had thrown himself, heart and soul, into the liberationist
Verse letter to B W Procter on the genesis and ambitions of Death's Jest-Book

..I have been

Giving some negro minutes of the night

Freed from the slavery of my ruling spright

Anatomy the grim, to a new story

In whose satiric pathos we will glory.

In it Despair has married wildest Mirth

And to their wedding-banquet all the earth

Is bade to bring its enmities and loves

Triumphs and horrors: you shall see the doves

Billing with quiet joy and all the while

Their nest's the scull of some old king of Nile:

But he who fills the cup and makes the jest

Pipes to the dancers, is the fool o' the feast.

Who's he? I've dug him up and decked him trim

And made a mock, a fool, a slave of him

Who was the planet's tyrant: dotard death:

Man's hate and dread: not with a stoical breath

To meet him like Augustus standing up,

Nor with grave saws to season the cold cup

Like the philosopher nor yet to hail

His coming with a verse or jesting tale

As Adrian did and More: but of his night

His moony ghostliness and silent might

To rob him, to un-cypress him $\mathrm{i}^{\prime}$ the light

To unmask all his secrets; make him play

Momus o'er the wine by torchlight is the way

To conquer him and kill; and from the day

Spurned hissed and hooted send him back again

An unmasked braggart to his bankrupt den.

For death is more 'a jest' than Life: you see

Contempt grows quick from familiarity.

I owe this wisdom to Anatomy-(Donner, ${ }^{8}$ pp 614-15)

politics of post-Napoleonic Europe. He lived in Zürich for seven years, respected as a man of science and letters, probably a practising homosexual, and by all accounts outspoken and eccentric: when its liberal government fell he was forced into a period of intellectual vagrancy. After a visit to London in the summer of 1840 he ended up, on the invitation of Dr Alfred Frey, a hospital physician, in Basle: it was no doubt an apt choice for a poet who now seemed bent on literary mortality, as the city from which Death danced out in the series of famous medieval woodcuts by Holbein (and dances across the cover of Edmund Gosse's The Complete Works of Thomas Lovell Beddoes, which was published in 1922). Paracelsus, with one foot in the occult and the other in modern medicine, had once lived in Basle too. Beddoes's final 10 month visit to London in 1846 was remembered years later for his drunken attempt to set fire to the Drury Lane playhouse with a lighted five pound note: that was his way of protesting against what he saw as the shoddiness of British theatre. His air of studied boorishness had tipped into a style of heroic contempt. His family thought he had gone quite mad. On a visit to Frankfurt with a Basle baker called Konrad Degen, Beddoes commissioned a theatre for a night in order to allow his friend to play Hotspur, presumably to an audience of one. A year after the wave of revolutions in 1848, back in Basle and perhaps dejected at his break with Degen, he finally succeeded in killing himself, having previously botched an attempt to open his arteries (poor show for an anatomist) and then had the gangrenous leg amputated; it was-ironically - the year which saw the Swiss Federation, alone on the continent, guarantee the kind of liberties he had fought for as a younger man. 
Many people have tried to disinter Beddoes's reputation from the oblivion one of his characters thought was "not so uncomfortable when one's got into the knack of it" only to see it stubbornly slump back into the thick Gothic mists of literary unconcern. ${ }^{12} \dagger \dagger$ In Beddoes's case, those mists may well be a persistently stagey cloud of his father's laughing gas. His father had once written about the respect that the dead should be shown in the anatomy room; his son spent most of his adult life making it resound to the "licentious conversation" and jests his father found so distasteful. ${ }^{13} \ddagger$

Despite the parricidal and fratricidal qualities he shares with Büchner, their posthumous reputations have been rather different. More disciplined by the question that tormented them both-"is No to blame for Yes or Yes for No?" (Woyzeck)-Büchner's voice was heard in all its distinctiveness only in the Germany of the 1910s, and his ribald sense of disillusionment has gone on to influence more than one generation of German writers: "German prose begins with Büchner's Lenz," according to Christa Wolf. Büchner was fairly explicit in attributing the crisis of reason to a Cartesian mystification of mind and reduction of bodily existence to something resembling that of an animate cadaver, a thrall not entirely unfamiliar to modern medicine. ${ }^{14}$ The living is only a species of the dead, and a rare species at that, as Nietzsche wrote ${ }^{15}$-a thought that gorgonised Beddoes, never a man for the light touch. If Beddoes, like Victor Frankenstein, aspired to be a "modern Prometheus", then he succeeded in overthrowing everything, even his belief in himself. The urge to curse was vitiated by a desperate need to regard himself as a failure, as the poet who "flowered and soured", in Christopher Ricks's words, in the 1820 s. ${ }^{16} \ddagger \ddagger$

†† The editors of Death's Jest-Book note, however, that "international interest in the poet and his work has never been greater": a "dramatic travesty" of Death's Jest-Book by J J McGann was even staged in summer 2003 in New York and Los Angeles. Beddoes's major work has also been reinterpreted in terms of an encoded homoerotic tale.

$F^{\prime \prime}$ It is not possible to conceive emotions more opposite than those excited by the aspect of a dead body, and by licentious conversation; or even by jests, from which, unfortunately, many persons of reflection, and, in other respects, of decent conduct, do not restrain themselves in the presence of boys. No power would afterwards be able to deprive the ideas, impressed by such a sight, of their serious complection." Thomas Lovell senior quoted by $\mathrm{H}$ W Donner. ${ }^{13}$

¥¥ In one of the best essays on Beddoes's poetry, Christopher Ricks makes a convincing argument for Beddoes as a poet who lived before his time, the 1830s being the decade in which Tennyson and Browning discovered the full possibilities of the dramatic monologue, "the most inaugurative of nineteenth century poetic kinds" ${ }^{\prime 16}$
Self contempt was the residue. The plea-or was it a prayer?-William Blake set out in a letter to George Cumberland on 12 April 1827 not long before his own death that year, never found Beddoes, to whom it could almost be addressed: "God keep me from the Divinity of Yes \& No too, the Yea Nay Creeping Jesus, from supposing Up and Down to be the same Thing as all Experimentalists must suppose ${ }^{\prime \prime} .{ }^{17}$

Strung between the urge to destroy what he wrote and to keep on writing regardless, Beddoes seems to have decided, 20 years before his act of self destruction that the "scenes of [his] existence" were actually the graveyard of his talent: Death's Jest-Book's recklessness suggests that as a young medical student in Göttingen he must have gone through a long dark night of the soul: his intellectual search to understand the how was an emotional need to grasp the why. Alas poor Beddoes!

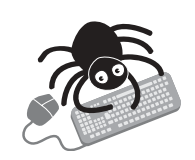

Further information may also be found at the website of the Thomas Lovell Beddoes' Society: www.beddoes.demon.co.uk.

\section{REFERENCES}

1 Higgens J, Bradshaw M, eds. Thomas Lovell Beddoes: selected poetry. Manchester: Carcanet, 1999:30-1.

2 Saintsbury G. A history of English prosody from the twelfth century to the present day vol III. London: Macmillan, 1910:150.

3 Porter R. Flesh in the age of reason. Harmondsworth: Allen Lane, 2003.

4 Porter R. Bodies politic: disease, death and doctors in Britain, 1650-1900. London: Reaktion Books, 2001:215-16.

5 Wilson F. Poetry is a horrible waste of time. London Review of Books 1999;21:28-29.

6 Coudert AP, Popkin RH, Weiner GM, eds. Leibniz, mysticism and religion. Amsterdam: Kluwer, 1998:84-106.

7 Beddoes TL. Death's jest-book. Manchester: Carcanet, 2003.

8 Donner HW, ed. The works of Thomas Lovell Beddoes. London: Oxford University Press, 1935:609.

9 Büchner G. Woyzeck, in: Sämtliche Werke [trans Bamforth I]. Weisbaden: Emil Vollmer Verlag, 1956:163-4.

10 Shelley M. Frankenstein or the modern Prometheus. Middlesex: Penguin, 1985:38-9.

11 Butler M. Frankenstein and radical science. In: Hunter JP, ed. Norton critical edition of Mary Shelley's Frankenstein. New York: W W Norton, 1996:302-13.

12 Rees S. Melveric and Wolfram: a love story. Journal of the Thomas Lovell Beddoes Society 2000;8:14-25.

13 Donner HW. Thomas Lovell Beddoes: the making of a poet. Oxford: Blackwell, 1935:49.

14 Reddick J. Introduction to Georg Büchner: complete plays, Lenz and other writings. Middlesex: Penguin, 1993:xx.

15 Nietzsche F. Die fröhliche Wissenschaft. Chemnitz: Ernst Schmeitzner, 1882:167-9.

16 Ricks C. The force of poetry. Oxford: Oxford University Press, 1984:150.

17 http://www.blakearchive.org/cgi-bin/nph-1965/blake/erdman/erd/ @GenericBookTextView/83855 (accessed 12 Mar 2004) 